\title{
CD105 (Endoglin): A Potential Anticancer Therapeutic Inhibits Mitogenesis and Map Kinase Pathway Activation
}

\author{
DONGHUI LIU ${ }^{1,2}$, SHANT KUMAR ${ }^{1,3}$, JASON ASHWORTH $^{1}$, KAMELA ALI $^{4}$, \\ ABDULMANNAN FADEL ${ }^{5}$, BAOQIANG GUO ${ }^{1}$ and MARK SLEVIN ${ }^{1,2}$ \\ ${ }^{I}$ School of Life Sciences, Manchester Metropolitan University, Manchester, U.K.; \\ ${ }^{2}$ The University of Medicine and Pharmacy of Targu Mures, Targu Mures, Romania; \\ ${ }^{3}$ Department of Pathology, Medical School, The University of Manchester, Manchester, U.K.; \\ ${ }^{4}$ Yanbu College of Applied Medical Sciences, Taibah University, Medina, Kingdom of Saudi Arabia; \\ ${ }^{5}$ School of Sport and Exercise Sciences, Liverpool John Moores University, Liverpool, U.K.
}

\begin{abstract}
Background: CD105 is highly expressed on human activated endothelial cells (ECs), is an important component of the TGF- $\beta 1$ receptor complex and is essential for angiogenesis. CD105 expression is up-regulated in activated ECs and is an important potential marker for cancer prognosis. Materials and Methods: In vitro rat myoblasts transfected with the L-CD105 and S-CD105 transfectants. The transfectants were treated with TGF- $\beta 1$ for the angiogenesis study. Results: L-CD105 affects cell proliferation in the presence and absence of TGF- $\beta 1$, and inhibits $p$-ERK1/2, p-MEK1/2 and p-c-Jun in L-CD105 transfectants compared to controls. The induction of phospho-ERK1/2 following treatment with TGF- $\beta 1$ remained significantly lower in L-CD105 transfectants compared to controls. Conclusion: L-CD105 inhibits the phosphorylation of ERK1/2, MEK1/2, c-Jun1/2/3, and associated signalling intermediates. CD105 modulates cell growth and TGF- $\beta 1$ induced cell signalling through ERK-c-Jun expression.
\end{abstract}

CD105 (Endoglin) is a $180-\mathrm{kDa}$ homodimeric integral transmembrane glycoprotein composed of disulphide-linked 90-95 kDa subunits and is a receptor component for TGF- $\beta 1$ and TGF- $\beta 3(1,2)$. It is primarily found on activated angiogenic endothelial cells (ECs) of microvessels of cancer and numerous other angiogenic diseases (3-8). CD105 regulates a wide range of cellular and physiological

This article is freely accessible online.

Correspondence to: Dr. Donghui Liu, E228, JD East, School of Life Sciences, Manchester Metropolitan University, Chester Street, Manchester, M1 5GD, U.K. Tel: +44 1612471172, e-mail: prcldh@hotmail.com

Key Words: CD105, MAPK, cell signalling, angiogenesis, TGF- $\beta 1$. responses, including embryonic development, homoeostasis, wound healing, chemotaxis, cell proliferation, differentiation, adhesion, migration, and apoptosis (4, 9-11). Overexpression of CD105 modulates TGF- $\beta$ signalling by interacting with TGF- $\beta$ receptor I (TGF- $\beta$ RI) and/or TGF$\beta$ receptor II (TGF- $\beta$ RII) on CD105 transfected L6E9 cells and human vascular smooth muscle cells through mitogenactivated protein kinases (MAPKs) $(12,13)$ and smallmothers-against-decapentaplegic (Smad) proteins $(14,15)$. Since CD105 overexpression was previously shown to be a marker of poor cancer outcome (16), and the phosphorylated ERK is a potential predictor of sensitivity to the treatment of carcinoma, as shown by various in vitro studies $(17,18)$, thus CD105 could be used as a potential therapy in cancer. Currently, CD105 is under phase 1 and phase 2 clinical trial in cancer patients (our and Seon et al.'s unpublished data).

CD105 has two isoforms, long-form L-CD105 and shortform S-CD105 (19), both of which bind to TGF- $\beta 1$ and TGF$\beta 3$. These two isoforms have contrasting roles in angiogenesis with L-CD105 being pro-angiogenic and S-CD105 inhibiting angiogenesis (20). Since L-CD105 is expressed at a markedly higher level than S-CD105 in ECs, the overall balance tends towards a pro-angiogenic phenotype in vivo (21).

The expression of CD105 on ECs and other cells is upregulated by both TGF- $\beta$ and hypoxia (22), but their additive effect is substantially greater than by themselves (23). Vascular lesions (telangiectasia and arteriovenous malformations) in CD105 haploinsufficient hereditary hemorrhagic telangiectasia type I (HHT1) patients are associated with a loss of the capillary network $(1,24)$. The association of mutations of the CD105 gene with HHT1 indicates the importance of CD105 for normal vascular architecture. Knockout mice for CD105 die in utero due to defective angiogenesis $(1,25)$.

Our previous and other studies have shown that CD105 is a critical marker for the quantification of microvessel density staining in numerous types of human tumours $(3,26-31)$ and 
Table I. List of selected proteins identified by Kinexus phospho-protein array.

\begin{tabular}{|c|c|c|c|c|c|c|c|}
\hline Protein name & $\begin{array}{l}\text { Abbreviation } \\
\text { epitope }\end{array}$ & L6M & L6L & L6S & T-L6M & T-L6L & T-L6S \\
\hline $\begin{array}{l}\text { Cyclin-dependent protein-serine } \\
\text { kinase } 1 / 2\end{array}$ & $\begin{array}{l}\text { CDK } 1 / 2 \\
\text { Y15 }\end{array}$ & $100 \%$ & $-16 \%$ & $18 \%$ & $164 \%$ & $54 \%$ & $85 \%$ \\
\hline $\begin{array}{l}\text { Extracellular regulated protein-serine } \\
\text { kinase } 1 \text { (p44 MAP kinase) }\end{array}$ & $\begin{array}{c}\text { ERK1 } \\
\text { T202+Y204 }\end{array}$ & $100 \%$ & $-89 \%$ & $-70 \%$ & $133 \%$ & $-18 \%$ & $24 \%$ \\
\hline $\begin{array}{l}\text { Extracellular regulated protein-serine } \\
\text { kinase } 2 \text { (p42 MAP kinase) }\end{array}$ & $\begin{array}{c}\text { ERK2 } \\
\text { T185+Y187 }\end{array}$ & $100 \%$ & $-70 \%$ & $11 \%$ & $123 \%$ & $-52 \%$ & $57 \%$ \\
\hline $\begin{array}{l}\text { c-Jun proto-oncogene-encoded } \\
\text { AP1 transcription factor }\end{array}$ & $\begin{array}{l}\text { c-Jun } \\
\text { S73 }\end{array}$ & $100 \%$ & $-88 \%$ & $-67 \%$ & $148 \%$ & $-44 \%$ & $-37 \%$ \\
\hline $\begin{array}{l}\text { MAPK/ERK protein-serine } \\
\text { kinase } 1 / 2(\text { MKK } 1 / 2)\end{array}$ & $\begin{array}{l}\text { MEK } 1 / 2 \\
\text { S217/S221 }\end{array}$ & $100 \%$ & $-55 \%$ & $-81 \%$ & $135 \%$ & $-5 \%$ & $-46 \%$ \\
\hline $\begin{array}{l}\text { MAP kinase protein-serine } \\
\text { kinase } 3 / 6(\mathrm{MKK} 3 / 6)\end{array}$ & $\begin{array}{c}\text { MEK3/6 } \\
\text { S189/S207 }\end{array}$ & $100 \%$ & $-63 \%$ & $-53 \%$ & $134 \%$ & $-31 \%$ & $-21 \%$ \\
\hline $\begin{array}{l}\text { Protein-serine } \\
\text { kinase } \mathrm{C} \alpha\end{array}$ & PKC $\alpha$ & $100 \%$ & $254 \%$ & $133 \%$ & $32 \%$ & $259 \%$ & $283 \%$ \\
\hline $\begin{array}{l}\text { Raf1 proto-oncogene-encoded } \\
\text { protein-serine kinase (S259) }\end{array}$ & Raf1 (60) & $100 \%$ & $13 \%$ & $159 \%$ & $66 \%$ & $144 \%$ & $236 \%$ \\
\hline $\begin{array}{l}\text { Src proto-oncogene-encoded } \\
\text { protein-tyrosine kinase (Y529) }\end{array}$ & Src (46) & $100 \%$ & $7 \%$ & $17 \%$ & $131 \%$ & $169 \%$ & $172 \%$ \\
\hline
\end{tabular}

T: TGF- $\beta 1$; L6M: Mock transfectants; L6L: L-CD105 transfectants; L6S: S-CD105 transfectants; T-L6M: TGF- $\beta 1$ treated mock transfectants; TL6L: TGF- $\beta 1$ treated L-CD105 transfectants; T-L6S: TGF- $\beta 1$ treated S-CD105 transfectants. The results from Kinexus protein array were shown and the proteins were normalised as count per minute (CPM). The changes of $25 \%$ were as significant.

is involved in TGF- $\beta 1$ induced cell signal transduction $(1,32-$ 35). Although, the intracellular mechanisms by which and how CD105 modulates TGF- $\beta 1$ signalling have been extensively studied, they need further clarification $(7,9,36-46)$.

The roles played by CD105 in the tumour angiogenesis and the development had been widely studied (47-51). Previous studies have shown that CD105 was expressed in many types of tumours $(22,52-56)$.

The microenvironment of solid tumours consists of heterogeneous cell types such as endothelial (ECs), inflammatory ( $\mathrm{T}$ cell and macrophages) mesenchymal stem (MSCs), fibroblasts, myofibroblasts (also called cancerassociated fibroblasts, CAFs), determines cancer prognosis (57-60). Most importantly apart from ECs, CD105 is also expressed on MSCs, CAFs and some subtypes of T-cells, is involved in their functional regulation and is a determinant of cancer development $(45,61)$. In an attempt to examine the role of CD105 on tumour angiogenesis and its effect on other cell types that are within the cancer microenvironment, we could not use human umbilical vein endothelial cells (HUVECs) or CAFs as a model system to overexpress CD105, because both these cell types express CD105 $(3,62,63)$. In this study, we chose to use rat myoblasts stably transfected with human CD105 to determine the downstream signalling mechanisms of CD105. This may lead to designing anticancer approaches. We found that overexpression of L-CD105 in rat myoblasts induced growth inhibition and reduced ERK phosphorylation. This finding is consistent with the previous publications that
CD105 expression in cancer cells inhibits their growth and metastasis (64-67).

\section{Materials and Methods}

Stable human CD105 transfection in rat myoblasts. Preparation of stable rat myoblast CD105 transfectants expressing human LCD105, S-CD105 and control mock transfectants was as described (68). No significant differences were observed between parental and mock transfectants in biochemical, functional and other studies (32).

Cell culture of human CD105 transfectants. The transfected rat myoblasts; mock (L6M), L-CD105 (L6L) and S-CD105 (L6S) transfectants were cultured in six-well plates $\left(2 \times 10^{5}\right.$ cells/well $)$ as previously described (32). The mock (L6M), L- and S-CD105 transfectants (L6L, L6S) were initially seeded in six-well plates $(2 \times 105$ cells/well $)$ and utilised for western blotting as described previously (69).

Quantification of cell viability. Human CD105 transfected rat myoblasts were seeded and maintained in six-well plates at $1 \times 10^{5}$ cells/well (32). Total cell counts were undertaken at $24 \mathrm{~h}, 48 \mathrm{~h}$ and $72 \mathrm{~h}$ and following trypsinisation using a Coulter Counter (Beckman Coulter, High Wycombe, UK).

Immediately after the cell counting, their viability was ascertained using $0.04 \%$ trypan blue. Four hundred cells were counted for each condition at every time point and the number of dead cells was expressed as a percentage of the total cell population. There were no significant differences in cell viabilities amongst the three kinds of transfected rat myoblasts (data not included). 
A

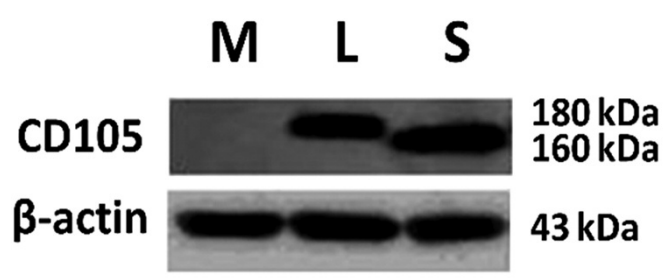

B

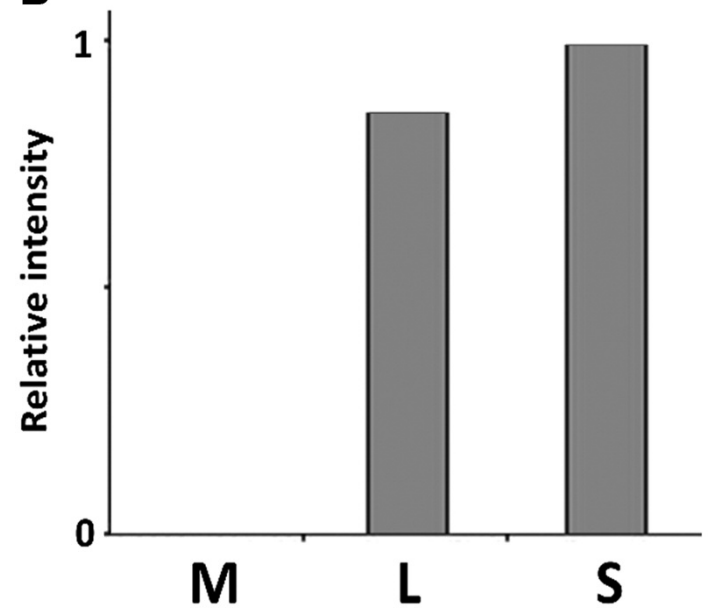

Figure 1. Western blotting showing that human CD105 were transfected into rat myoblasts successfully, whereas L-CD105 protein was overexpressed in L6L and S-CD105 protein was overexpressed L6S cells, but there was no CD105 expression in mock cells. $\beta$-actin was used as a loading control. The data are representative of two experiments of duplicate samples. M: Mock, L6M cells; L: L6L cells; S: L6S cells.

Cell proliferation following stimulation with TGF- $\beta 1$. Human CD105 transfectants were cultured in six-well plates at a density of $1 \times 10^{5}$ cells/well in $2 \mathrm{ml}$ complete Dulbecco's Modified Eagle Medium (DMEM) containing TGF- $\beta 1$ ( $5 \mathrm{ng} / \mathrm{ml}$, R\&D Systems, Oxford, UK), in a humidified $5 \% \mathrm{CO}_{2} /$ air atmosphere incubator at $37^{\circ} \mathrm{C}$. After $48 \mathrm{~h}$ following trypsinisation, the cell numbers were counted using a Coulter Counter (Beckman Coulter, High Wycombe, UK).

Cell culture and protein extraction for western blot. L6M, L6L and L6S cells were seeded at $2 \times 10^{5} /$ well in DMEM supplemented with $10 \%$ FBS, $2 \mathrm{mM}$ L-glutamine and $1 \%$ antibiotics $(10 \mathrm{U} / \mathrm{ml}$ penicillin and $100 \mu \mathrm{g} / \mathrm{ml}$ streptomycin) in 6-well plate and incubated in a water-saturated, $5 \% \mathrm{CO}_{2}$ incubator at $37^{\circ} \mathrm{C}$. For each experiment, the cells were starved in serum poor medium (cells were incubated in $1 \%$ FBS DMEM for $24 \mathrm{~h}$ ) prior to the assay.

For the TGF- $\beta 1$ treatment study, the un-confluent starved cells were treated with TGF- $\beta 1$ ( $5 \mathrm{ng} / \mathrm{ml}$, R\&D Systems, Oxford, UK) for $5 \mathrm{~min}, 10 \mathrm{~min}$ and $30 \mathrm{~min}$ respectively. The cells were washed twice with ice-cold PBS and then were lysed by adding ice-cold Kinexus Lysis Buffer (Kinexus service, Vancouver, British Columbia, Canada) $300 \mu \mathrm{l} /$ well and incubated on ice for $1 \mathrm{~min}$ and then using a cell scraper to collect the cell lysates. After that, the cell lysates were transferred into a $1.5 \mathrm{ml}$ Eppendorf tube and continued incubated on ice for $20 \mathrm{~min}$. During the incubation, the cell lysates were sonicated every $2 \mathrm{~min}$. Subsequently, the lysates were centrifuged at $10,000 \times g$ for $10 \mathrm{~min}$ at $4^{\circ} \mathrm{C}$. The supernatants were collected, and aliquots stored at $-80^{\circ} \mathrm{C}$ for later use.

Protein estimation and western blotting. Protein concentration was estimated using a BCA Protein Reagents (ThermoFisher Scientific, Cambridge, UK). The protein samples (30 $\mu \mathrm{g}$ of each) were processed under reducing conditions by adding equal volumes of 2fold concentrated sample buffer and then subjected to $10 \%$ SDSPAGE (70).
Kinetworks ${ }^{T M}$ Phospho-site protein Screen assay. Human CD105 transfected rat myoblasts were seeded $\left(4 \times 10^{5}\right.$ cells/dish $)$ in $10 \mathrm{ml}$ cell culture dishes (32). Sub-confluent cells were treated with TGF$\beta 1(5 \mathrm{ng} / \mathrm{ml})$ for $10 \mathrm{~min}$ and lysed with $1 \mathrm{ml}$ of ice-cold cell lysis buffer (Kinexus, Vancouver, British Columbia, Canada). All cell lysates were sonicated twice (15 sec each time), and then incubated on ice for $20 \mathrm{~min}$ before ultracentrifugation for $30 \mathrm{~min}$ at $1 \times 10^{5} \mathrm{~g}$ at $4^{\circ} \mathrm{C}$. The resulting supernatant fractions were collected and assayed for protein concentration using a BCA Protein Reagents (ThermoFisher Scientific, Cambridge, UK) and adjusted to $1 \mathrm{mg} / \mathrm{ml}$ prior to use in the KPSS-1.3 protein array (Table I).

Statistical analysis. All data are presented as the mean \pm standard deviation from at least 3 independent experiments and were analysed using GraphPad Prism software version 7.0 for Windows (GraphPad Software, San Diego, CA, USA). The values were compared using a paired Student's $t$-test. The differences at $p<0.05$ were considered statistically significant.

\section{Results}

Western blotting showed that human CD105 was expressed in both L6L and L6S cells but not in mock cells (Figure 1), wherein $\beta$-actin was used as a loading control. Figure 1 is representative of two separate experiments that gave similar results. All the experiments were repeated at least twice.

Cell growth studies demonstrated that in complete medium, L6M control cells grew significantly faster than L6L cells ( $n=3, p<0.05$; Figure 2) at 24 h, 48 h and 72 h. In contrast, L6S cell growth was not significantly $(\mathrm{p}>0.05)$ different to control L6M cells on any of the time points.

Furthermore, L6M cells in the presence and absence of TGF- $\beta 1$ grew significantly faster than L6L cells over $72 \mathrm{~h}$ 


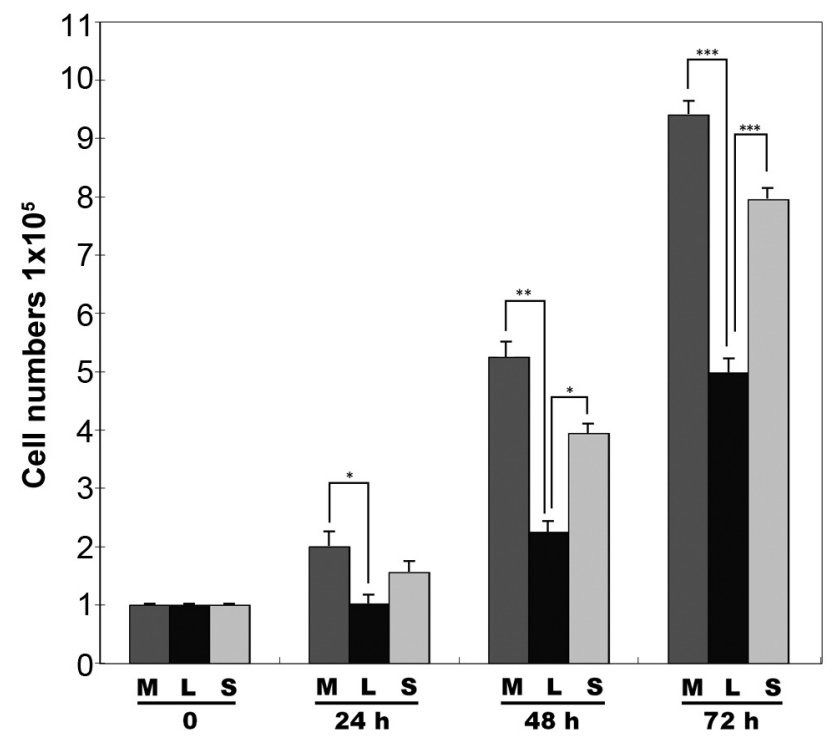

Figure 2. Cell proliferation assay showing a significant decrease in $L 6 L$ after $24 h$ and $72 h$ of treatment $(n=3 ; p<0.05)$. However, there was only a slight non-significant decrease in L6S cells, compared to L6M cells. The data represent results from three experiments, with samples measured in triplicate for each experiment. M: L6M cells; L: L6L cells; S: L6S cells.

$(\mathrm{n}=3, p<0.05$; Figure 3$)$. The proliferation of L6L cells following TGF- $\beta 1$ treatment was almost completely nullified within $72 \mathrm{~h}(\mathrm{n}=3, p<0.05)$ compared to control mock cells without TGF- $\beta 1$ stimulation (Figure 3 ). Figure 3 is representative of two separate experiments, utilising triplicate samples.

Cell signal transduction activation was analysed by a Kinexus phospho-protein (KPSS-1.3) array. De-regulated phosphorylated proteins were identified and showed a notable reduction of phospho-ERK1/2, phospho-MEK1/2, and phospho-c-Jun in L-CD105 transfectants (L6L) compared to mock cells (L6M). Whilst, all these proteins were less decreased in S-CD105 transfectants (L6S) compared to L-CD105 transfectants (L6L). Figure 4 shows phospho-ERK1/2, phospho-MEK1/2, and phospho-c-Jun expression were up-regulated after TGF- $\beta 1$ treatment in both L-CD105 and S-CD105 transfectants. The total proteins extracted from human CD105 transfected rat myoblasts in the Kinexus phospho-protein western screening (KPSS-1.3) array were detected by $10 \%$ SDS-PAGE, with $\beta$-actin used as a loading control. In all cases, data were obtained from duplicate spots in the Kinexus array.

ERK $1 / 2$ is implicated in cell signalling via the TGF- $\beta 1$ receptor. Western blotting results (Figure 5) showed the basal level of p-ERK1/2 in L6M cells was substantially higher than in both L6L and L6S cells. The p-ERK1/2 level was higher in L6S cells than in L6L cells. Figure 4 shows p-

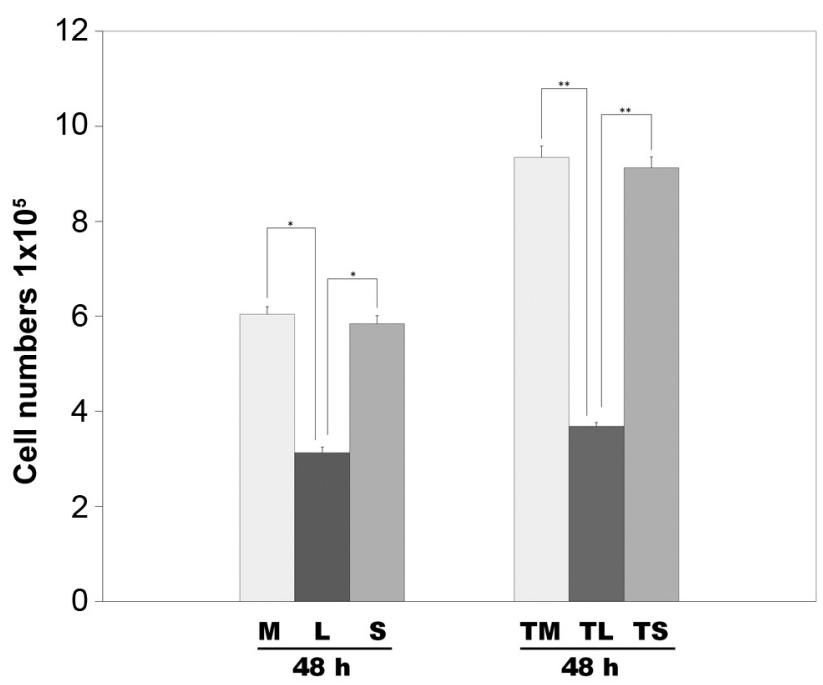

Figure 3. Cell proliferation assay displaying a significant inhibition in L6L cells after $72 h$ (significant, $n=3, p<0.05$ ) with and without TGFb1 treatment compared to control (mock cells without TGF-b1 treatment). Data represent results from three experiments, with samples measured in triplicate for each experiment. M: L6M cells; L: L6L cells; S: L6S cells; TM: TGF-b1 treated L6M cells; TL: TGF-b1 treated L6L cells; TS: TGF-b1 treated L6S cells.

ERK1/2 and p-MEK1/2 were significantly increased in both L6M and L6S cells. p-c-Jun1/2/3 was increased in TGF- $\beta 1$ treated L6M cells, but less so in TGF- $\beta 1$ treated L6L cells. p-c-Jun $1 / 2 / 3$ expression was at lower levels either in the presence or in the absence of TGF- $\beta 1$ in both L6L and L6S ells, but the L6L cells had decreased more than the L6S cells. In all cases, $\beta$-actin was used as a loading control and data represent results from two separate experiments of duplicate samples.

To examine ERK1/2 expression associated with TGF- $\beta 1$ signalling in transfected rat myoblasts, the cell lines were stimulated with TGF- $\beta 1$ at various times. Following treatment with human TGF- $\beta 1$, the ERK1/2 was activated within $10 \mathrm{~min}$ in mock (L6M) cells (Figure 5A). In TGF- $\beta 1$ treated L6L cells, p-ERK1/2 increased within 5 min and peaked at $10 \mathrm{~min}$, although it remained significantly lower $(p<0.05)$ than in mock cells. After peaking at $10 \mathrm{~min}, \mathrm{p}-$ ERK1/2 declined gradually in L6L cells treated with TGF$\beta 1$ but remained above basal levels (untreated L6L cells) after $8 \mathrm{~h}$ (data not shown). Similarly in TGF- $\beta 1$ treated L6S cells (where the basal levels were higher than in L6L cells but lower than in mock cells), p-ERK1/2 increased at $5 \mathrm{~min}$, peaked at $10 \mathrm{~min}$, and thereafter began to decline in a similar pattern to that observed in L-CD105 transfected cells. The results showed that the relative increase in ERK1/2 activation was lower in L-CD105 transfectants compared with S-CD105 transfectants and mock cells. 
A

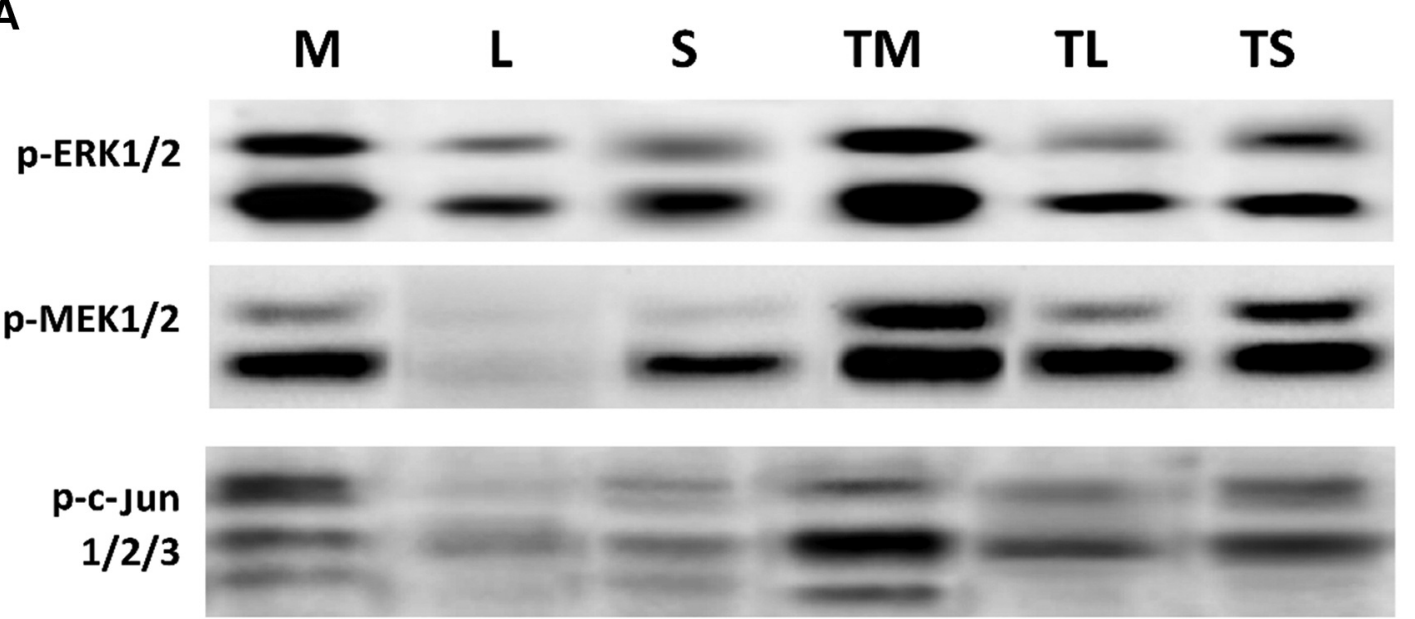

44 kDa

42 kDa

54 kDa

46 kDa

$42 \mathrm{KDa}$

$40 \mathrm{kDa}$

$39 \mathrm{kDa}$

$\beta$-actin

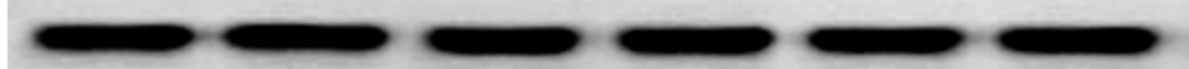

43 kDa

\section{B}
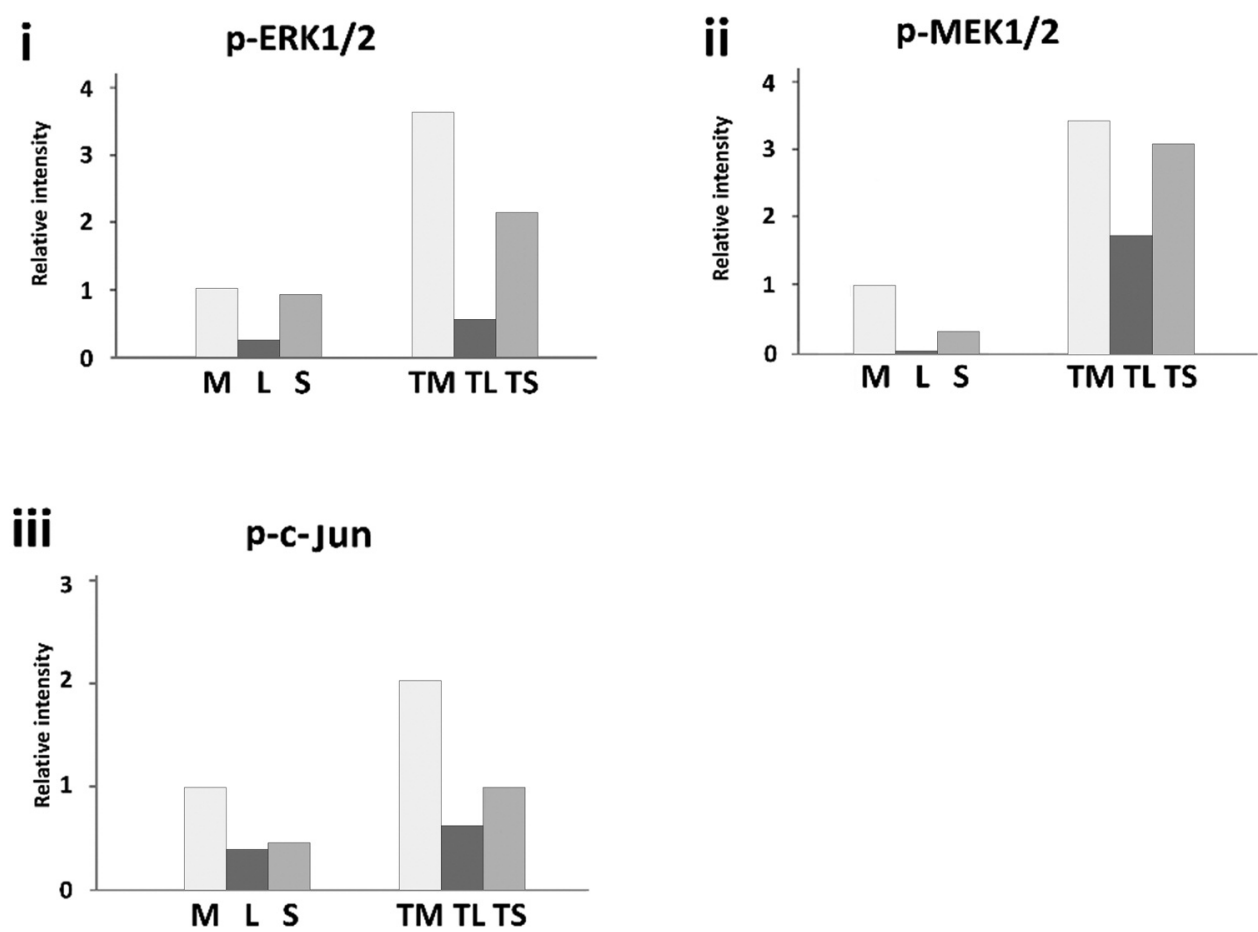

Figure 4. Proteomics study showing phosphorylated proteins in L6M, L6L, and L6S cells. Since CD105 appears to influence the activation of multiple signalling pathways, its effects on intracellular signal transduction in rat myoblast human CD105 transfectants were analysed using a Kinexus phospho-protein Western screening (KPSS-1.3) array. De-regulated phospho-proteins in both L-CD105 and S-CD105 transfectants were observed compared to control (mock transfectants). There was a significant reduction $(n=3, p<0.05)$ in $p$-ERK1/2, $p$-MEK1/2, and $p$-c-Jun1/2/3 in L6L, compared to mock cells (control), whereas L6S cells were less affected. After TGF- $\beta 1$ treatment for 10 min, the p-ERK1/2, MEK1/2 and p-c-Jun were up-regulated in L6M and L6S but were less in L6L cells. The count per minute from Kinexus highlighted significant differences among the L6M, L6L, and L6S cells. The data represent a single experiment with proteins separated and analysed in duplicate. M: L6M cells; L: L6L cells; S: L6S cells; TM: TGF-b1 treated L6M cells; TL: TGF-b1 treated L6L cells; TS: TGF-b1 treated L6S cells. 


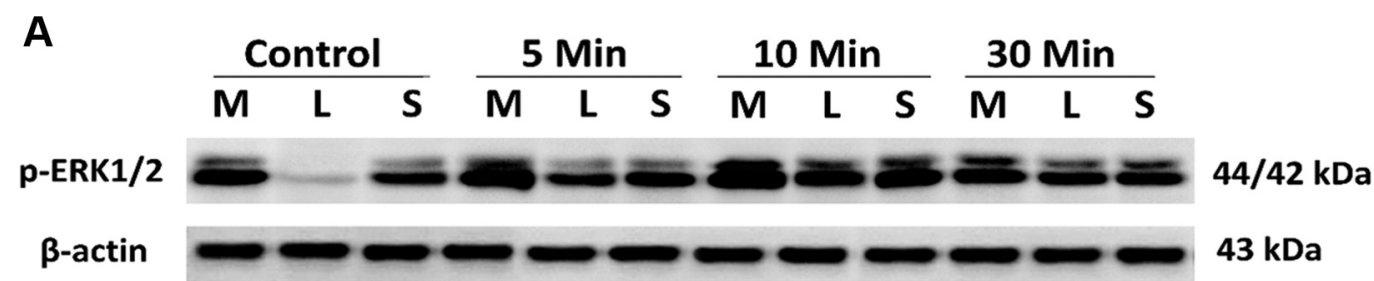

B

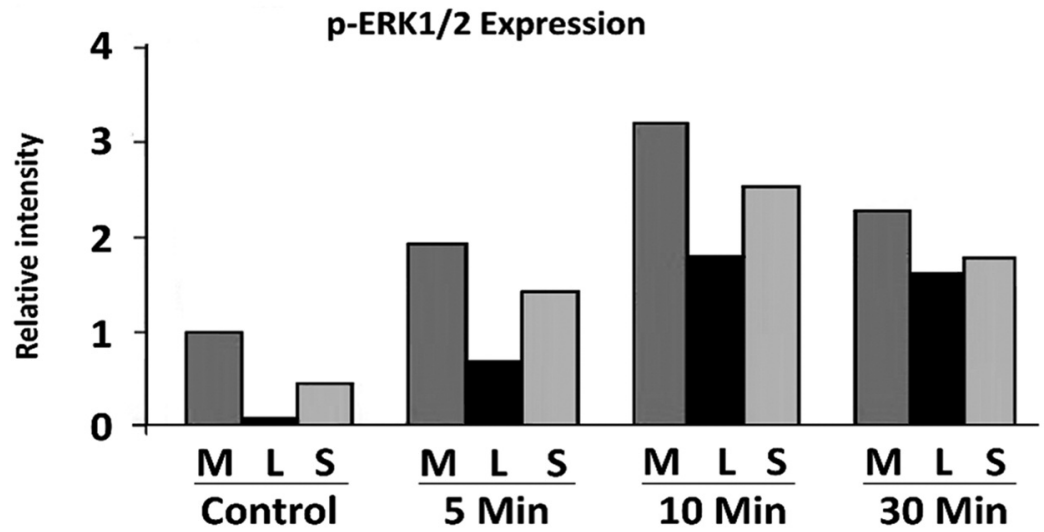

Figure 5. Western blot results demonstrates the phosphorylation of ERK1/2 (A) in L6L, L6S and L6M cells. The bar graph (B) suggests that the phosphorylation of ERK1/2 was notably reduced in L6L after TGF-b1 treatment, while weaker inhibition was observed in L6S cells compared to L6M (control) cells. $\beta$-actin was used as a loading control. The basal levels of p-ERK1/2 in L6M cells was much higher than that in L6L cells. Following treatment with TGF-b1, p-ERK1/2 in L6M cells increased after 5 min and peaked after 10 min, showing similar levels to those in L6S. In L6L cells, after TGF-b1 treatment, p-ERK1/2 was also noticeably increased at 5 min, peaked at 10 min (but remained much lower than in L6M cells), and thereafter declined. L6S cells showed a steady increase after TGF- $\beta 1$ treatment. Data are representative of two experiments with duplicate samples in each experiment. M: Mock, L6M cells; L: L6L cells; S: L6S cells.

\section{Discussion}

CD105 is predominantly expressed in angiogenic vascular ECs in different types of cancers. It forms a complex with the TGF- $\beta$ receptor and is able to modify TGF- $\beta 1$-mediated signalling pathways $(1,71)$. Like previous studies, Ilhan et al. concluded that overexpression of CD105 in colorectal cancers was associated with tumour angiogenesis and poor prognosis (8). However, the mechanism through which CD105 interacts with TGF- $\beta 1$ and how it interacts with intracellular signalling pathways is not fully elucidated.

An important finding emerging from this study is that mitogenesis/cell proliferation was reduced in both L- and SCD105 transfectants compared to mock cells. Unexpectantly, L6L cells grew significantly more slowly than L6S cells, that contrasts with a previous publication (72). Further, TGF- $\beta 1$ induced proliferation of L-CD105 transfectants. We hypothesise that chronic overexpression of this receptor could lead to antagonistic or receptor feedback mechanisms which reduce the expression of phospho-ERK1/2 in these cells. In our phospho-protein study, ERK1/2, MEK1/2, and c-Jun1/2/3 were down-regulated in the L-CD105 but less so in S-CD105 transfectants. As ERK is a key pro-mitogenic signalling intermediate, reduction in its expression/activation normally leads to reduced cell proliferation. This explains the fact that compared to L6M (mock transfectants), L6L cells grew more slowly than L6S cells.

This is the first study to show that both ERK, MEK and c-Jun phospho-protein expression is suppressed in rat myoblast CD105 transfectants. Specifically, western blot analysis revealed that phospho-ERK1/2 was significantly inhibited in both L-CD105 and S-CD105 transfectants. As previously reported, c-Jun plays an essential role in organogenesis during mouse embryonic development by regulating cell survival, apoptosis, and proliferation $(73,74)$. Therefore, it is possible that inhibition of the c-Jun pathway may influence proliferation in L-CD105 transfectants.

Although the phosphorylation of ERK remained inducible in CD105 transfected rat myoblasts after stimulation by TGF- $\beta 1$, the presence of the L-CD105 isoform significantly attenuated this response $(12,14)$. Chronic activation of the TGF- $\beta 1$ receptor by L-CD105 may have resulted in selfdown-regulation or indeed induction in the activation of key signalling intermediates such as MEK, responsible for ERK 


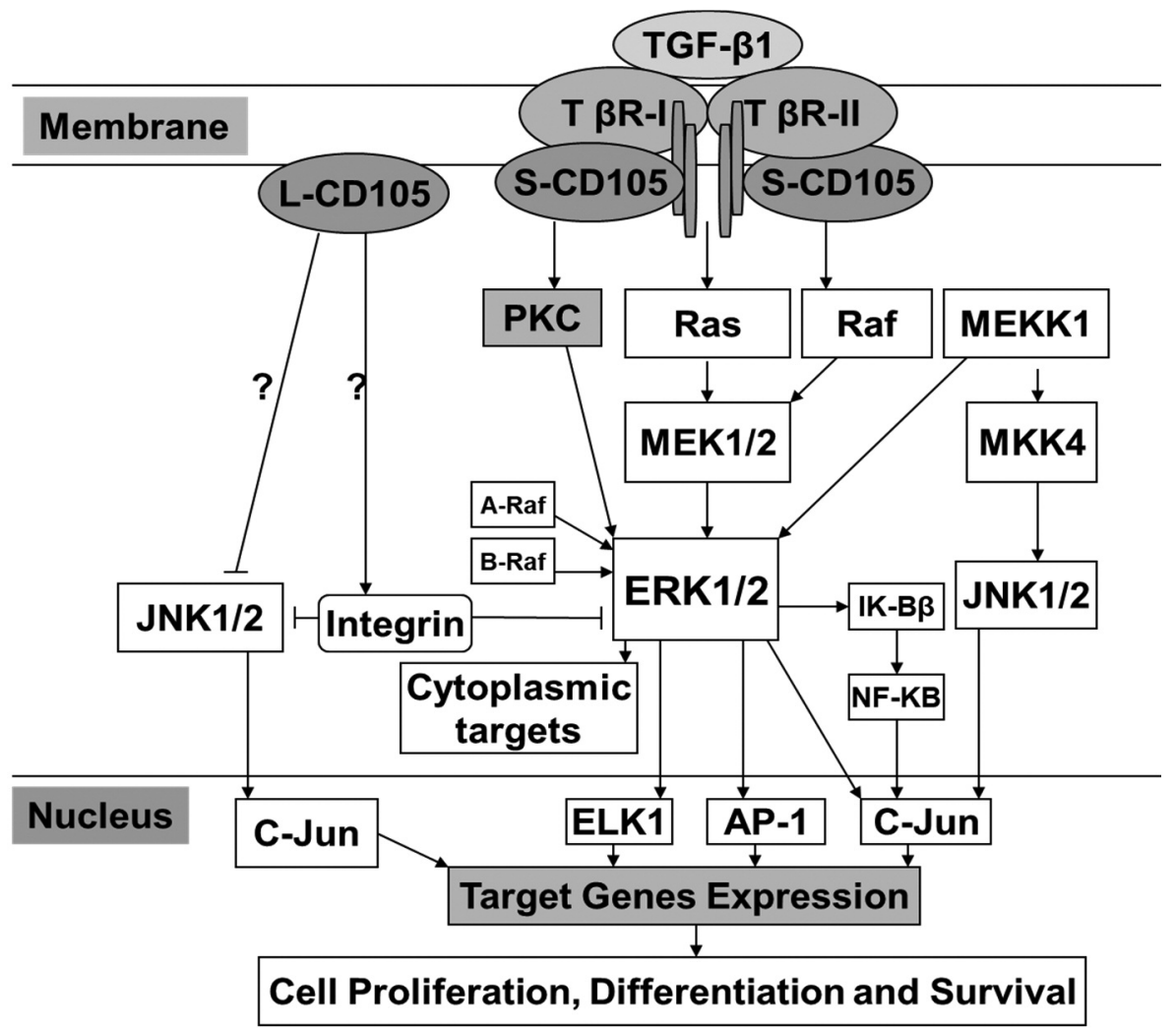

Figure 6. Schematic diagram representation of the TGF- $\beta 1 / E R K / c-J u n$ pathway regulation by the long and short form of CD105 that ultimately determines endothelial cell proliferation, differentiation and survival. TGF- $\beta 1$ stimulates ERK in the cell signalling pathway. Activation of the ERK pathway is most often associated with cell proliferation and cell survival. Well-characterized inhibitors of Raf-1 and MEK1/2 and the interaction of CD105 and TGF- $\beta 1$ in cell signalling pathways are highlighted. Chronic overexpression of L-CD105 may play a negative role in TGF- $\beta 1$ induced MAPK signalling pathway in human CD105 transfected rat myoblasts by a negative feedback mechanism or over-stimulation of ERK1/2 phosphorylation/activation [for more details see reference (78)].

phosphorylation. Taken together, these data suggest that over-expression of CD105 in rat myoblast transfectants may play an important role in the modulation of the ERK signalling pathway via TGF- $\beta 1$ signalling in these cells.

Previously we demonstrated that the phosphorylation of Smad3 was inhibited by CD105, which also inhibited TGF$\beta 1$-Smad3 signalling. Overexpression of CD105 leads to phosphorylation of JNK, but there are no additive/synergistic effects on the JNK phosphorylation after TGF- $\beta 1$ treatment. And CD105 may either prohibit TGF- $\beta 1 / \mathrm{Smad} 3$ signalling or inhibit the transcriptional activity of Smad3 up-regulating the phosphorylation of JNK (14). Here we found that overexpression of CD105 is also associated with the inhibition of p-ERK expression in rat myoblasts transfected with human CD105, and this might either interact with smad3 or act alone through ERK1/2. The stimulation of TGF- $\beta 1$ activates the ERK MAP kinase (69), but the exact role of ERK in the modulation of the TGF- $\beta 1$ signalling pathway is unclear $(71,75,76)$. We hypothesise that the over-expression of human L-CD105 in these cells modulates TGF- $\beta 1$ induced cell signalling and this occurs primarily through the ERK and c-Jun signalling pathways other than the smad3 pathway, but the detailed mechanisms need further exploration.

The decrease of p-ERK1/2 in L-CD105 transfectants may differently influence cell signalling, depending on which type of cell is under consideration. Although our data demonstrate that L-CD105 modulates TGF- $\beta 1$ induced cell signalling through a pathway involving ERK-c-Jun expression in human CD105 transfectants in vitro, further work is required to identify other participants in TGF- $\beta 1$ signalling pathway in these transfected cells. Similarly, the reduction in c-Jun expression could inhibit Smad 2/3 phosphorylation, and vice versa, the activation of c-Jun stimulated by TGF- $\beta 1$ can induce the phosphorylation of Smad $2 / 3$ both in vivo and in vitro $(76,77)$.

In summary, we demonstrated that the phosphorylation of ERK is chronically decreased in the L-CD105 transfectants. The two isoforms of the human CD105 result in differences in gene 
expression, in binding and activating the target genes and/or proteins, as well as in the regulation of cell mitogenesis (20).

In conclusion, CD105 modulates cell growth and TGF- $\beta 1$ induced cell signalling through a pathway involving ERK-cJun expression in human CD105 transfectants in vitro and that over-expression of L-form of CD105 may inhibit cell growth by modulating phosphorylation/activation of the ERK/c-Jun map kinase pathways (Figure 6).

\section{Conflicts of Interest}

All the Authors confirm that there are no conflicts of interest for this study.

\section{Authors' Contributions}

D Liu and J Ashworth drafted and edited the paper. D Liu carried out the cell culture, prepared the samples for the Kinexus study and western blot. K Ali performed proliferation assay, part of the western blot. A Fadel did the statistical analysis. B Guo contributed to the draft and figures. S Kumar and M Slevin designed the study and supervised the project.

\section{Acknowledgements}

The Authors are grateful to Professor Carmelo Bernabeu for kindly providing the rat myoblasts, and Dr Chenggang Li for his greatly appreciated help and advice. This work was supported by a grant from Cancer Research UK.

\section{References}

1 Li C, Hampson IN, Hampson L, Kumar P, Bernabeu C and Kumar S: CD105 antagonizes the inhibitory signaling of transforming growth factor beta1 on human vascular endothelial cells. FASEB J 14(1): 55-64, 2000. PMID: 10627280. DOI: 10.1096/fasebj.14.1.55

2 Lee NY and Blobe GC: The interaction of endoglin with betaarrestin2 regulates transforming growth factor-beta-mediated ERK activation and migration in endothelial cells. J Biol Chem 282(29): 21507-21517, 2007. PMID: 17540773. DOI: 10.1074/jbc.M700176200

3 Duff SE, Li C, Garland JM and Kumar S: CD105 is important for angiogenesis: evidence and potential applications. FASEB J 17(9): 984-992, 2003. PMID: 12773481. DOI: 10.1096/fj.020634rev

4 Fonsatti E and Maio M: Highlights on endoglin (CD105): from basic findings towards clinical applications in human cancer. $\mathrm{J}$ Transl Med 2(1): 18, 2004. PMID: 15193152. DOI: 10.1186/14795876-2-18

5 Park S, Sorenson CM and Sheibani N: PECAM-1 isoforms, eNOS and endoglin axis in regulation of angiogenesis. Clin Sci (Lond) 129(3): 217-234, 2015. PMID: 25976664. DOI: $10.1042 / C S 20140714$

6 Chadchan SB, Kumar V, Maurya VK, Soni UK and Jha RK: Endoglin (CD105) coordinates the process of endometrial receptivity for embryo implantation. Mol Cell Endocrinol 425: 69-83, 2016. PMID: 26802878. DOI: 10.1016/j.mce.2016.01.014
7 Ollauri-Ibáñez C, Núñez-Gómez E, Egido-Turrión C, SilvaSousa L, Díaz-Rodríguez E, Rodríguez-Barbero A, López-Novoa $\mathrm{JM}$ and Pericacho M: Continuous endoglin (CD105) overexpression disrupts angiogenesis and facilitates tumor cell metastasis. Angiogenesis 23(2): 231-247, 2020. PMID: 31897911. DOI: $10.1007 / \mathrm{s} 10456-019-09703-y$

8 Ilhan N, Gungor H, Gul HF and Eroksuz H: Expression of endoglin and vascular endothelial growth factor as prognostic markers in experimental colorectal cancer. Anticancer Res 36(8): 3953-3959, 2016. PMID: 27466499

9 Valluru M, Staton CA, Reed MW and Brown NJ: Transforming growth factor $\beta$ and endoglin signaling orchestrate wound healing. Front Physiol 2: 89, 2011. PMID: 22164144. DOI: 10.3389/fphys.2011.00089

10 Jonker L: TGF- $\beta$ \& BMP receptors endoglin and ALK1: overview of their functional role and status as antiangiogenic targets. Microcirculation 21(2): 93-103, 2014. PMID: 25279424. DOI: $10.1111 /$ micc.12099

11 Kato M, Placencio-Hickok VR, Madhav A, Haldar S, Tripathi M, Billet S, Mishra R, Smith B, Rohena-Rivera K, Agarwal P, Duong F, Angara B, Hickok D, Liu Z and Bhowmick NA: Heterogeneous cancer-associated fibroblast population potentiates neuroendocrine differentiation and castrate resistance in a CD105-dependent manner. Oncogene 38(5): 716-730, 2019. PMID: 30177832. DOI: 10.1038/s41388-018-0461-3

12 Rodríguez-Barbero A, Obreo J, Alvarez-Munoz P, Pandiella A, Bernabéu C and López-Novoa JM: Endoglin modulation of TGF-beta1-induced collagen synthesis is dependent on ERK1/2 MAPK activation. Cell Physiol Biochem 18(1-3): 135-42, 2006. PMID: 16914898. DOI: 10.1159/000095181

13 Redondo S, Ruiz E, Gordillo-Moscoso A, Navarro-Dorado J, Ramajo M, Carnero M, Reguillo F, Rodriguez E and Tejerina T: Role of TGF-betal and MAP kinases in the antiproliferative effect of aspirin in human vascular smooth muscle cells. PLoS One 5(3): e9800, 2010. PMID: 20339548. DOI: 10.1371/journal.pone. 0009800

14 Guo B, Slevin M, Li C, Parameshwar S, Liu D, Kumar P, Bernabeu C and Kumar S: CD105 inhibits transforming growth factor-beta-Smad3 signalling. Anticancer Res 24(3a): 13371345, 2004. PMID: 15274293

15 Pannu J, Nakerakanti S, Smith E, ten Dijke P and Trojanowska M: Transforming growth factor-beta receptor type I-dependent fibrogenic gene program is mediated via activation of Smad1 and ERK1/2 pathways. J Biol Chem 282(14): 10405-10413, 2007. PMID: 17317656. DOI: 10.1074/jbc.M611742200

16 Zimmerer RM, Korn P, Demougin P, Kampmann A, Kokemüller $\mathrm{H}$, Eckardt AM, Gellrich NC and Tavassol F: Functional features of cancer stem cells in melanoma cell lines. Cancer Cell Int 13(1): 78, 2013. PMID: 23915418. DOI: 10.1186/1475-2867-13-78

17 Zhang Z, Zhou X, Shen H, Wang D and Wang Y: Phosphorylated ERK is a potential predictor of sensitivity to sorafenib when treating hepatocellular carcinoma: evidence from an in vitro study. BMC Med 7: 41, 2009. PMID: 19698189. DOI: 10.1186/1741-7015-7-41

18 Degirmenci $\mathrm{U}$, Wang $\mathrm{M}$ and $\mathrm{Hu} \mathrm{J}$ : Targeting aberrant RAS/RAF/MEK/ERK signaling for cancer therapy. Cells 9(1): 198, 2020. PMID: 31941155. DOI: 10.3390/cells9010198

19 Pérez-Gómez E, Del Castillo G, Juan Francisco S, López-Novoa JM, Bernabéu C and Quintanilla M: The role of the TGF- $\beta$ coreceptor endoglin in cancer. ScientificWorldJournal 10: 23672384, 2010. PMID: 21170488. DOI: 10.1100/tsw.2010.230 
20 Pérez-Gómez E, Eleno N, López-Novoa JM, Ramirez JR, Velasco B, Letarte M, Bernabéu C and Quintanilla M: Characterization of murine S-endoglin isoform and its effects on tumor development. Oncogene 24(27): 4450-4461, 2005. PMID: 15806144. DOI: 10.1038/sj.onc.1208644

$21 \mathrm{Li} \mathrm{C}$, Guo B, Bernabeu C and Kumar S: Angiogenesis in breast cancer: the role of transforming growth factor beta and CD105. Microsc Res Tech 52(4): 437-449, 2001. PMID: 11170303. DOI: 10.1002/1097-0029(20010215)52:4<437::AID-JEMT 1 $029>3.0 . \mathrm{CO} ; 2-\mathrm{G}$

22 Rosen LS, Gordon MS, Robert F and Matei DE: Endoglin for targeted cancer treatment. Curr Oncol Rep 16(2): 365, 2014. PMID: 24445497. DOI: 10.1007/s11912-013-0365-x

23 Sánchez-Elsner T, Botella LM, Velasco B, Langa C and Bernabéu C: Endoglin expression is regulated by transcriptional cooperation between the hypoxia and transforming growth factor-beta pathways. J Biol Chem 277(46): 43799-43808, 2002. PMID: 12228247. DOI: 10.1074/jbc.M207160200

24 Sorensen LK, Brooke BS, Li DY and Urness LD: Loss of distinct arterial and venous boundaries in mice lacking endoglin, a vascular-specific TGFbeta coreceptor. Dev Biol 261(1): 235250, 2003. PMID: 12941632. DOI: 10.1016/s00121606(03)00158-1

25 Li DY, Sorensen LK, Brooke BS, Urness LD, Davis EC, Taylor DG, Boak BB and Wendel DP: Defective angiogenesis in mice lacking endoglin. Science 284(5419): 1534-1537, 1999. PMID: 10348742. DOI: $10.1126 /$ science.284.5419.1534

26 Ding S, Li C, Lin S, Yang Y, Liu D, Han Y, Zhang Y, Li L, Zhou $\mathrm{L}$ and Kumar S: Comparative evaluation of microvessel density determined by CD34 or CD105 in benign and malignant gastric lesions. Hum Pathol 37(7): 861-866, 2006. PMID: 16784986. DOI: 10.1016/j.humpath.2006.02.006

27 Saroufim A, Messai Y, Hasmim M, Rioux N, Iacovelli R, Verhoest G, Bensalah K, Patard JJ, Albiges L, Azzarone B, Escudier B and Chouaib S: Tumoral CD105 is a novel independent prognostic marker for prognosis in clear-cell renal cell carcinoma. Br J Cancer 110(7): 1778-1784, 2014. PMID: 24594997. DOI: $10.1038 /$ bjc.2014.71

28 Ciocâlteu A, Săftoiu A, Pirici D, Georgescu CV, Cârţână T, Gheonea DI, Gruionu LG, Cristea CG and Gruionu G: Tumor neoangiogenesis detection by confocal laser endomicroscopy and anti-CD105 antibody: Pilot study. World J Gastrointest Oncol 7(11): 361-368, 2015. PMID: 26600936. DOI: 10.4251/wjgo.v7.i11.361

29 Martinez LM, Labovsky V, Calcagno Mde L, Davies KM, Rivello HG, Wernicke A, Calvo JC and Chasseing NA: Comparative prognostic relevance of breast intra-tumoral microvessel density evaluated by CD105 and CD146: A pilot study of 42 cases. Pathol Res Pract 212(4): 350-355, 2016. PMID: 26872535. DOI: 10.1016/j.prp.2016.02.009

30 Nomura Y, Yamashita T, Oishi N, Nio K, Hayashi T, Yoshida M, Hayashi T, Hashiba T, Asahina Y, Okada H, Sunagozaka H, Takatori H, Honda M and Kaneko S: De novo emergence of mesenchymal stem-like $\mathrm{CD} 105^{+}$cancer cells by cytotoxic agents in human hepatocellular carcinoma. Transl Oncol 10(2): 184189, 2017. PMID: 28182993. DOI: 10.1016/j.tranon.2017.01.005

31 Shahar T, Rozovski U, Hess KR, Hossain A, Gumin J, Gao F, Fuller GN, Goodman L, Sulman EP and Lang FF: Percentage of mesenchymal stem cells in high-grade glioma tumor samples correlates with patient survival. Neuro Oncol 19(5): 660-668, 2017. PMID: 28453745. DOI: 10.1093/neuonc/now239
32 Guo B, Rooney P, Slevin M, Li C, Parameshwar S, Liu D, Kumar P, Bernabeu C and Kumar S: Overexpression of CD105 in rat myoblasts: role of CD105 in cell attachment, spreading and survival. Int J Oncol 25(2): 285-291, 2004. PMID: 15254724

33 Kopczyńska E and Makarewicz R: Endoglin - a marker of vascular endothelial cell proliferation in cancer. Contemp Oncol (Pozn) 16(1): 68-71, 2012. PMID: 23788858. DOI: 10.5114/wo.2012.27340

34 Browne S, Jha AK, Ameri K, Marcus SG, Yeghiazarians Y and Healy KE: TGF- $\beta 1 /$ CD 105 signaling controls vascular network formation within growth factor sequestering hyaluronic acid hydrogels. PLoS One 13(3): e0194679, 2018. PMID: 29566045. DOI: 10.1371/journal.pone.0194679

35 Nair S, Nayak $R$, Bhat $K$, Kotrashetti VS and Babji D: Immunohistochemical expression of CD105 and TGF- $\beta 1$ in oral squamous cell carcinoma and adjacent apparently normal oral mucosa and its correlation with clinicopathologic features. Appl Immunohistochem Mol Morphol 24(1): 35-41, 2016. PMID: 25710582. DOI: 10.1097/PAI.0000000000000152

36 Meurer SK, Alsamman M, Sahin H, Wasmuth HE, Kisseleva T, Brenner DA, Trautwein C, Weiskirchen R and Scholten D: Overexpression of endoglin modulates TGF- $\beta 1$-signalling pathways in a novel immortalized mouse hepatic stellate cell line. PLoS One 8(2): e56116, 2013. PMID: 23437087. DOI: 10.1371/journal.pone.0056116

37 Alsamman M, Sterzer V, Meurer SK, Sahin H, Schaeper U, Kuscuoglu D, Strnad P, Weiskirchen R, Trautwein C and Scholten D: Endoglin in human liver disease and murine models of liver fibrosis-A protective factor against liver fibrosis. Liver Int 38(5): 858-867, 2018. PMID: 28941022. DOI: 10.1111/liv.13595

38 Bai S, Zhu W, Coffman L, Vlad A, Schwartz LE, Elishaev E, Drapkin R and Buckanovich RJ: CD105 Is Expressed in ovarian cancer precursor lesions and is required for metastasis to the ovary. Cancers (Basel) 11(11): 1710, 2019. PMID: 31684072. DOI: $10.3390 /$ cancers 11111710

39 Kim SK, Henen MA and Hinck AP: Structural biology of betaglycan and endoglin, membrane-bound co-receptors of the TGF-beta family. Exp Biol Med (Maywood) 244(17): 1547-1558, 2019. PMID: 31601110 . DOI: $10.1177 / 1535370219881160$

$40 \mathrm{Oh}$ MK and Kim IS: Involvement of placental growth factor upregulated via TGF- $\beta 1$-ALK1-Smad1/5 signaling in prohaptoglobin-induced angiogenesis. PLoS One 14(4): e0216289, 2019. PMID: 31034502. DOI: 10.1371/journal.pone.0216289

41 Walker DG, Lue LF, Beach TG and Tooyama I: Microglial phenotyping in neurodegenerative disease brains: Identification of Reactive Microglia with an antibody to variant of CD105/endoglin. Cells 8(7): 766, 2019. PMID: 31340569. DOI: 10.3390/cells8070766

42 Gerrits T, Zandbergen M, Wolterbeek R, Bruijn JA, Baelde HJ and Scharpfenecker $\mathrm{M}$ : Endoglin promotes myofibroblast differentiation and extracellular matrix production in diabetic nephropathy. Int J Mol Sci 21(20): 7713, 2020. PMID: 33081058. DOI: $10.3390 / \mathrm{ijms} 21207713$

43 Lee Y, Lee J, Nam SK and Hoon Jun Y: S-endoglin expression is induced in hyperoxia and contributes to altered pulmonary angiogenesis in bronchopulmonary dysplasia development. Sci Rep 10(1): 3043, 2020. PMID: 32080296. DOI: 10.1038/s41598020-59928-x

44 Meurer SK and Weiskirchen R: Endoglin: An 'accessory' receptor regulating blood cell development and inflammation. 
Int J Mol Sci 21(23): 9247, 2020. PMID: 33287465. DOI: 10.3390/ijms 21239247

45 Schoonderwoerd MJA, Goumans MTH and Hawinkels LJAC: Endoglin: Beyond the endothelium. Biomolecules 10(2): 289, 2020. PMID: 32059544. DOI: 10.3390/biom10020289

46 Vidal AC, Duong F, Howard LE, Wiggins E, Freedland SJ, Bhowmick NA and Gong J: Soluble endoglin (sCD105) as a novel biomarker for detecting aggressive prostate cancer. Anticancer Res 40(3): 1459-1462, 2020. PMID: 32132043. DOI: 10.21873/anticanres.14088

47 Kumar P, Wang JM and Bernabeu C: CD 105 and angiogenesis. J Pathol 178(4): 363-366, 1996. PMID: 8691311. DOI: $10.1002 /($ SICI) 1096-9896(199604)178:4<363::AIDPATH491>3.0.CO;2-8

48 Paauwe M, ten Dijke P and Hawinkels LJ: Endoglin for tumor imaging and targeted cancer therapy. Expert Opin Ther Targets 17(4): 421-435, 2013. PMID: 23327677. DOI: $10.1517 / 147282$ 22.2013.758716

49 ten Dijke P, Goumans MJ and Pardali E: Endoglin in angiogenesis and vascular diseases. Angiogenesis 11(1): 79-89, 2008. PMID: 18283546. DOI: 10.1007/s10456-008-9101-9

50 Seon BK, Haba A, Matsuno F, Takahashi N, Tsujie M, She X, Harada N, Uneda S, Tsujie T, Toi H, Tsai H and Haruta Y: Endoglin-targeted cancer therapy. Curr Drug Deliv 8(1): 13543, 2011. PMID: 21034418. DOI: 10.2174/156720111793663 570

51 Kasprzak A and Adamek A: Role of endoglin (CD105) in the progression of hepatocellular carcinoma and anti-angiogenic therapy. Int J Mol Sci 19(12): 3887, 2018. PMID: 30563158. DOI: 10.3390/ijms19123887

52 Postiglione L, Di Domenico G, Caraglia M, Marra M, Giuberti G, Del Vecchio L, Montagnani S, Macri M, Bruno EM, Abbruzzese A and Rossi G: Differential expression and cytoplasm/membrane distribution of endoglin (CD105) in human tumour cell lines: Implications in the modulation of cell proliferation. Int J Oncol 26(5): 1193-1201, 2005. PMID: 15809709. DOI: 10.3892/ ijo.26.5.1193

53 Nassiri F, Cusimano MD, Scheithauer BW, Rotondo F, Fazio A, Yousef GM, Syro LV, Kovacs K and Lloyd RV: Endoglin (CD105): a review of its role in angiogenesis and tumor diagnosis, progression and therapy. Anticancer Res 31(6): 22832290, 2011. PMID: 21737653

54 Guo JL, Gu SQ, Li Y and Zhang XY: Evaluation of clinical significance of endoglin expression during breast cancer and its correlation with ER and PCNA. Eur Rev Med Pharmacol Sci 21(23): 5402-5407, 2017. PMID: 29243782. DOI: 10.26355/ eurrev_201712_13927

55 Saeednejad Zanjani L, Madjd Z, Abolhasani M, Shariftabrizi A, Rasti A and Asgari M: Expression of CD105 cancer stem cell marker in three subtypes of renal cell carcinoma. Cancer Biomark 21(4): 821-837, 2018. PMID: 29286924. DOI: 10.3233/CBM170755

56 Zhang J, Zhang L, Lin Q, Ren W and Xu G: Prognostic value of endoglin-assessed microvessel density in cancer patients: a systematic review and meta-analysis. Oncotarget 9(7): 76607671, 2017. PMID: 29484142. DOI: 10.18632/oncotarget. 23546

57 Orimo A and Weinberg RA: Stromal fibroblasts in cancer: a novel tumor-promoting cell type. Cell Cycle 5(15): 1597-601, 2006. PMID: 16880743. DOI: 10.4161/cc.5.15.3112
58 Joyce JA and Pollard JW: Microenvironmental regulation of metastasis. Nat Rev Cancer 9(4): 239-252, 2009. PMID: 19279573. DOI: $10.1038 / \mathrm{nrc} 2618$

59 Delinasios JG, Angeli F, Koumakis G, Kumar S, Kang WH, Sica G, Iacopino F, Lama G, Lamprecht S, Sigal-Batikoff I, Tsangaris GT, Farfarelos CD, Farfarelos MC, Vairaktaris E, Vassiliou S and Delinasios GJ: Proliferating fibroblasts and HeLa cells cocultured in vitro reciprocally influence growth patterns, protein expression, chromatin features and cell survival. Anticancer Res 35(4): 1881-1916, 2015. PMID: 25862842

60 Friedman G, Levi-Galibov O, David E, Bornstein C, Giladi A, Dadiani M, Mayo A, Halperin C, Pevsner-Fischer M and LavonPashot H: Cancer-associated fibroblast compositions change with breast cancer progression linking S100A4 and PDPN ratios with clinical outcome. bioRxiv, 2020. DOI: 10.1101/2020.01.12.903039

61 Houthuijzen JM and Jonkers J: Cancer-associated fibroblasts as key regulators of the breast cancer tumor microenvironment. Cancer Metastasis Rev 37(4): 577-597, 2018. PMID: 30465162. DOI: $10.1007 / \mathrm{s} 10555-018-9768-3$

62 Bok JS, Byun SH, Park BW, Kang YH, Lee SL, Rho GJ, Hwang SC, Woo DK, Lee HJ and Byun JH: The role of human umbilical vein endothelial cells in osteogenic differentiation of dental follicle-derived stem cells in in vitro co-cultures. Int $\mathrm{J}$ Med Sci 15(11): 1160-1170, 2018. PMID: 30123053. DOI: 10.7150/ijms.27318

63 Kocherova I, Bryja A, Mozdziak P, Angelova Volponi A, Dyszkiewicz-Konwińska M, Piotrowska-Kempisty H, Antosik P, Bukowska D, Bruska M, Iżycki D, Zabel M, Nowicki M and Kempisty B: Human umbilical vein endothelial cells (huvecs) co-culture with osteogenic cells: from molecular communication to engineering prevascularised bone grafts. J Clin Med 8(10): 1602, 2019. PMID: 31623330. DOI: 10.3390/jcm8101602

64 Craft CS, Romero D, Vary CP and Bergan RC: Endoglin inhibits prostate cancer motility via activation of the ALK2-Smad1 pathway. Oncogene 26(51): 7240-7250, 2007. PMID: 17496924. DOI: $10.1038 /$ sj.onc.1210533

65 Lakshman M, Huang X, Ananthanarayanan V, Jovanovic B, Liu Y, Craft CS, Romero D, Vary CP and Bergan RC: Endoglin suppresses human prostate cancer metastasis. Clin Exp Metastasis 28(1): 39-53, 2011. PMID: 20981476. DOI: 10.1007/s10585-010-9356-6

66 Romero D, O’Neill C, Terzic A, Contois L, Young K, Conley BA, Bergan RC, Brooks PC and Vary CP: Endoglin regulates cancer-stromal cell interactions in prostate tumors. Cancer Res 71(10): 3482-3493, 2011. PMID: 21444673. DOI: 10.1158/00085472.CAN-10-2665

67 Li Y, Zhai Z, Liu D, Zhong X, Meng X, Yang Q, Liu J and Li $\mathrm{H}$ : CD105 promotes hepatocarcinoma cell invasion and metastasis through VEGF. Tumour Biol 36(2): 737-745, 2015. PMID: 25286761. DOI: 10.1007/s13277-014-2686-2

68 Letamendía A, Lastres P, Botella LM, Raab U, Langa C, Velasco $\mathrm{B}$, Attisano L and Bernabeu C: Role of endoglin in cellular responses to transforming growth factor-beta. A comparative study with betaglycan. J Biol Chem 273(49): 33011-33019, 1998. PMID: 9830054 . DOI: 10.1074/jbc.273.49.33011

69 Lee MK, Pardoux C, Hall MC, Lee PS, Warburton D, Qing J, Smith SM and Derynck R: TGF-beta activates Erk MAP kinase signalling through direct phosphorylation of ShcA. EMBO J 26(17): 3957-3967, 2007. PMID: 17673906. DOI: 10.1038/ sj.emboj. 7601818 
70 Liu D, Andrade SP, Castro PR, Treacy J, Ashworth J and Slevin $\mathrm{M}$ : Low concentration of sodium butyrate from ultrabraid $+\mathrm{NaBu}$ suture, promotes angiogenesis and tissue remodelling in tendonbones injury. Sci Rep 6: 34649, 2016. PMID: 27694930. DOI: 10.1038/srep34649

71 Fang WH, Ahmed M, Wang Q, Li HM, Kumar P and Kumar S: PAX3 promotes tumor progression via CD105 signaling. Microvasc Res 86: 42-43, 2013. PMID: 23274166. DOI: 10.1016/j.mvr.2012.12.005

72 Velasco S, Alvarez-Muñoz P, Pericacho M, Dijke PT, Bernabéu C, López-Novoa JM and Rodríguez-Barbero A: L- and Sendoglin differentially modulate TGFbeta 1 signaling mediated by ALK1 and ALK5 in L6E9 myoblasts. J Cell Sci 121(Pt 6): 913-919, 2008. PMID: 18303046. DOI: $10.1242 /$ jcs.023283

73 Nishina $H$, Wada $T$ and Katada T: Physiological roles of SAPK/JNK signaling pathway. J Biochem 136(2): 123-126, 2004. PMID: 15496581 . DOI: $10.1093 / \mathrm{jb} / \mathrm{mvh} 117$

74 Noy N. Between death and survival: retinoic acid in regulation of apoptosis. Annu Rev Nutr 30: 201-217, 2010. PMID: 20415582. DOI: 10.1146/annurev.nutr.28.061807.155509

75 Javelaud D and Mauviel A: Crosstalk mechanisms between the mitogen-activated protein kinase pathways and Smad signaling downstream of TGF-beta: implications for carcinogenesis. Oncogene 24(37): 5742-5750, 2005. PMID: 16123807. DOI: $10.1038 /$ sj.onc. 1208928
76 Suzuki K, Wilkes MC, Garamszegi N, Edens M and Leof EB: Transforming growth factor beta signaling via Ras in mesenchymal cells requires p21-activated kinase 2 for extracellular signal-regulated kinase-dependent transcriptional responses. Cancer Res 67(8): 3673-3682, 2007. PMID: 17440079. DOI: 10.1158/0008-5472.CAN-06-3211

77 Yamagata H, Matsuzaki K, Mori S, Yoshida K, Tahashi Y, Furukawa F, Sekimoto G, Watanabe T, Uemura Y, Sakaida N, Yoshioka K, Kamiyama Y, Seki T and Okazaki K: Acceleration of Smad2 and Smad3 phosphorylation via c-Jun NH(2)-terminal kinase during human colorectal carcinogenesis. Cancer Res 65(1): 157-165, 2005. PMID: 15665291.

78 Guo B, Kumar S, Li C, Slevin M and Kumar P: CD105 (endoglin), apoptosis, and stroke. Stroke 35(5): e94-95, 2004. PMID: 15060327. DOI: 10.1161/01.STR.0000125309.37971.82

Received January 11, 2021

Revised January 26, 2021

Accepted February 1, 2021 